\title{
PERFORMANCE AND CARCASS CHARACTERISTICS OF DUMYATI, MUSCOVY, PEKING AND SUDANI DUCK BREEDS
}

\author{
A. Galal ${ }^{1}$, W.A.H. Ali ${ }^{2}$, A.M.H. Ahmed ${ }^{1}$ and Kh. A.A. Ali ${ }^{2}$ \\ 1- Department of Poultry Production, Faculty of Agriculture, Ain Shams \\ University, Cairo, Egypt, 2- Department of Rabbit, Turkey and Waterfowl, \\ Breeding Research, Animal Production Research Institute, Ministry of \\ Agriculture, Dokki, Giza, Egypt
}

\section{SUMMARY}

This experiment was conducted on 120 ducks (30 Dumyati, 30 Peking, 30 Muscovy and 30 Sudani ducks). The ducks were fed complete commercial diets, appropriate for respective species. Slaughter and slaughter value estimation were performed at the age of 12 weeks. Analysis of the chemical composition of meat was made on breast and thigh muscles. Cell-mediated immunity was examined by Phytohemagglutinin-P (PHA-P) at 10 weeks of age. The present result showed that Muscovy strain had significantly heavier body weight compared to remaining strains. Concerning sexual dimorphism, the Sudani strain has a greater dimorphism in body size between males and females(51.8\%) followed by Muscovy (43.7\%). Both Muscovy and Peking ducks possess better feed conversion ratio than Dumyati and Sudani. Regardless of breed effect, the males had significantly heavier body weight with more efficient feed conversion ratio than females. The Muscovy breed possesses better quality of meat than the Peking one due to lower body fat. With respect to cellmediated immunity, the present results showed that Dumyati breed in both sexes had significantly hyper responder to PHA-P injection at all times compared to other breeds. The results obtained in this study give some insight into the production parameters and immune response of the four breeds of ducks present in Egypt.

Keywords: duck breeds, meat quality, immune response

\section{INTRODUCTION}

There is an increasing demand for animal protein, and duck production may be able to help meet this demand. Ducks are able to adapt to a wide range of environmental and natural conditions, which may be the reason for the increasing importance, and popularity of the duck industry in Egypt. The duck meat is a food with a protein content of more than $20 \%$ along with a favorable amino-acid composition. The meat itself is not really fatty; its fat content is approximately $2 \%$ according to Szasz and Bogenfurst (1998), whereas according to Pikul et al. (1987) it is $4.7-5.8 \%$. However, under the skin of domestic duck a considerable amount of fat is deposited. Although the adiposity is not favorable in nutritional aspect, the duck meat consumption shows a rising tendency in the high-quality-demanding markets.

Issued by The Egyptian Society of Animal Production 
This is due, in particular, to the versatility of the products and demand for specialties. The fat content of the body in domestic ducks has been lowered by different breeding procedures; however, the special taste of the meat still remained.

The Muscovy is popular due to its red gamy meat, and the attractively marbled meat of the mule duck is a special delicacy. These two genotypes differ from the domestic duck in many respects, especially in the lower fat content of the body and in the meat quality. Duck feather is not as valuable as goose feather, but it is still a popular product. Similarly to geese, the stripped feather of live animals and the plucked feather of slaughtered ones constitute the stock fund. Muscovy ducks in particular is a heavy breed mainly used for meat production, since the meat has an appealing look with yellow creamy skin and is firm. Szasz (2003) reported that Muscovy is popular due to its red gamy and attractively marbled meat which makes for special delicacy. The best slaughter age of ducks was found between 7 and 8 weeks of life (Bochno et al., 1988). Within this range, the meat content of carcass was the highest and meat to fat ratio proved the most favorable (Bochno et al., 1984). When the age of the ducks exceeds 8 weeks the muscles no longer gain in weight, while the gain of skin with subcutaneous fat increases (Górski 1990, 1997a,b). Chemical composition of breast and leg muscles are crucial for the culinary value and technological properties of duck meat and have been investigated by many authors in relation to the birds' origin, age and nutrition (Knust and Pingel 1992, Witkiewicz 2000 and Wołoszyn et al., 2002). The aim of this study was to evaluate of carcass characteristics, meat quality and immune status of the four breeds of ducks presented in Egypt.

\section{MATERIALS AND METHODS}

\section{Genetic flocks and husbandry:}

One hundred and twenty, day old, male and female ducklings of the Dumyati, Muscovy, Pekin and Muscovy breed types were used in study. The ducklings were reared for ten weeks using an intensive system of management. During the first three weeks, the ducklings were reared in separate brooding pens and for the last seven weeks in separate growing pens, which were made safe from predators. Ducklings were raised on concrete floors with five centimeters thick wood shaving as bedding and infrared light was used as the source of heat. A brooding space of 60 square $\mathrm{cm}$ was provided for each duckling. Initially brooding temperature was maintained at $32^{\circ} \mathrm{C}$, but this was reduced by $5^{\circ} \mathrm{C}$ per week, until the end of the brooding period at three weeks of age. Wind and air drifts during the first three weeks were controlled by curtains placed around the pens. Each duckling was provided with a feeding and watering space of 3-5 cm and 2-4 cm, respectively depending on the age of the ducklings. Starter ration in the form of a dry mash with $21 \%$ crude protein was given from day one to three weeks of age. A known quantity of feed was provided ad libitum and refusals collected and weighed on a daily basis. Water was available ad libitum and bottles were filled twice daily. After the three weeks brooding period was over the ducklings were shifted to a separate grower house and reared on a concrete floor with $4 \mathrm{~cm}$ thick wood shaving, up to the end of the experiment. A floor space of 100 -sq. cm per bird was provided. A feeding and watering space of $6 \mathrm{~cm}$ and $5 \mathrm{~cm}$ respectively was provided for each bird. A grower/finisher feed in the form of a dry 
mash with $16 \%$ crude protein was gradually introduced at this stage to completion of trial. Ducklings were weighed individually.

\section{Dissection and quality of carcass:}

After ten weeks, five males and five females from each breed were randomly selected and slaughtered to determine the dressing weight and other carcass characteristics. After plucking and cooling for about $20 \mathrm{~min}$., the carcasses were eviscerated and divided into breast muscles, leg muscles, skin with fat, and abdominal fat. To determine the meat chemical composition, breast muscles as well as leg and lower thigh muscles of the same leg were taken from each carcass side and then analyzed individually. Chemical composition of the breast and leg muscles (water, protein, fat, ash) was determined with routine procedures.

\section{Cell-mediated immunity:}

Response induced in vivo by mitogen was evaluated by injection of phytohemagglutinin-P (PHA-P) into the toe-web. At 10 weeks of age, 5 duck chicks from each breed were used. Each duck was intradermally injected in the toe-web with $100 \mu$ g PHA-P (Sigma Chemical Co., St. Louis, MO 63178). The toe-web thickness was measured with a constant tension caliper before injection and at 24, 48 and $72 \mathrm{hr}$ after PHA-P injection. The toe-web swelling was calculated as the difference between the thickness of the toe web before and after injection.

\section{Statistical analysis:}

Data were subjected to a two -way analyses of variance with breed and sex effect using the General Linear Model (GLM) procedure of SAS User's Guide (2001).

\section{RESULTS AND DISCUSSION}

\section{Live performance:}

The mean live body weight as reported in Table (1) revealed that the Muscovy breed had significantly heaviest body weight compared to remaining breeds. However, there was no significant difference between Peking and Sudani breeds. Concerning sex effect, it could be observed that the males had significantly heavier body weight than those of females. With respect sexual dimorphism, the Sudani strain (51.85) has a greater dimorphism in body size between males and females followed by Muscovy (43.7\%) one. Bochno et al. (1994) reported live body weight at slaughter (8-10 weeks) for the Muscovy to be $2.29 \mathrm{~kg}$ and that the Muscovy has a greater dimorphism in body size between males and females. Males grew faster and yielded heavier body weight than females. A similar trend was observed by Van der Sluis (1993) in relation to Muscovy ducks and their growth rates. Bochno et al. (1994) also reported that male ducks grew faster with more efficient feed conversion than females. The Muscovy drake is almost twice the size of the female, while in the Pekin duck the difference is small (3-5\%) (Sauveur, 1990). Also, Wiseman (1987) reported that a feature of the Muscovy duck breed is the large sexual dimorphism, and after 10-12 weeks of age, the body weight of the female is only $65 \%$ of that of the drake. 
As expected, the Muscovy strain consumed significantly more feed compared to other genetic group follow by Sudani breed. Similar trend was noticed for Sudani breed when compared with remaining breeds. Inversely, there was no significant difference between Dumyati and Peking breeds. In accordance to feed conversion ratio, the present results indicated that both Muscovy and Peking strains posses better feed conversion ratio than Dumyati and Sudani ones. Bochno et al. (1994) reported that feed conversion was more efficient in Muscovy ducks than Pekin. Perez (1985) showed that Pekin ducks had a feed conversion at 8 weeks of $2.83 \mathrm{~kg}$ feed $/ \mathrm{kg}$ live weight gain. Other researchers (Duong and Nguyen 1995; Luong et al., 1995) reported feed conversion ratios of 2.91 and $2.77 \mathrm{~kg}$ feed $/ \mathrm{kg}$ live weight gain respectively, for commercial ducks reared intensively.

Table 1. Body weight, feed consumption and feed conversion ratio of ducks as affected by strain, sex and their interaction

\begin{tabular}{|c|c|c|c|c|c|c|c|c|c|}
\hline \multirow[b]{2}{*}{ Sex } & \multicolumn{4}{|c|}{ Breed } & \multirow[b]{2}{*}{ Overall } & \multirow{2}{*}{$\begin{array}{l}\text { Pooled } \\
\text { S.E.M }\end{array}$} & \multicolumn{2}{|c|}{$\begin{array}{l}\text { Level } \\
\text { significance }\end{array}$} & \multirow{2}{*}{$\begin{array}{r}\text { of } \\
* S \\
\end{array}$} \\
\hline & Dumyati & Muscovy & Peking & Sudani & & & $\mathrm{B}$ & $\mathrm{S}$ & \\
\hline \multicolumn{10}{|c|}{ Body weight, g } \\
\hline Female & 1587 & 2467 & 2015 & 1761 & $1958^{\mathrm{b}}$ & 71.14 & & & \\
\hline Male & 1758 & 3546 & 2627 & 2673 & $2651^{\mathrm{a}}$ & 80.67 & & & \\
\hline Overall & $1673^{\mathrm{c}}$ & $3007^{\mathrm{a}}$ & $2321^{\mathrm{b}}$ & $2217^{\mathrm{b}}$ & & & 0.01 & 0.001 & NS \\
\hline \multicolumn{10}{|c|}{ Feed consumption, $\mathrm{g}$} \\
\hline Female & 5275 & 5825 & 5058 & 5307 & $5366^{\mathrm{b}}$ & 69.24 & & & \\
\hline Male & 5669 & 8136 & 6186 & 7429 & $6855^{\mathrm{a}}$ & 74.63 & & & \\
\hline Overall & $5472^{c}$ & $6981^{\mathrm{a}}$ & $5622^{c}$ & $6368^{b}$ & & & 0.01 & 0.001 & NS \\
\hline \multicolumn{10}{|c|}{ Feed conversion ratio } \\
\hline Female & 3.41 & 2.42 & 2.57 & 3.10 & $2.64 b$ & 0.12 & & & \\
\hline Male & 3.30 & 2.33 & 2.41 & 2.83 & $2.81 \mathrm{a}$ & 0.14 & & & \\
\hline Overall & $3.35^{\mathrm{a}}$ & $2.37^{\mathrm{d}}$ & $2.48^{c}$ & $2.94^{\mathrm{b}}$ & & & 0.01 & 0.001 & NS \\
\hline
\end{tabular}

\section{Carcass characteristics:}

Effect of strain, sex and their interaction on relative carcass characteristics of ducks is summarized in Table (2). It could be noticed that the relative blood weight was significantly affected by strain, whereas the Sudani strain recorded the highest values (6.07\%), however, the Muscovy strain recorded the lowest values $(5.79 \%)$. Regardless strain, the males had significantly higher blood percentage than those of females. Moreover, the relative blood weight was significantly affected by interaction between strain and sex. The last result could be attributed to, within strains, the effect of sex on blood percentage was more pronounced in both Muscovy and Sudani strains rather than Dumyati and Peking ones.

Concerning relative feather weight, the present result showedthat the Dumyati and Peking strains possess higher relative feather weight compared to Muscovy and Sudani ones. It was observed that the female ducks irrespective of their breed tends to have lower feather percentage than the males.

The dressing percentage is a trait of economic importance. The present result revealed that the Muscovy ducks gave the significantly highest dressing percentage of 71.22 and 69.54 for male and female, respectively. The high dressing percentage recorded in Muscovy might be due to the fact that this breed is a heavy breed which 
has been highly regarded for meat production. Also, two possible reasons for the tendency for higher dressed and eviscerated percentages of the Muscovy ducks are less plumage and smaller internal organs when compared to the other strains. Carew et al. (1998) found that dressing percentage of ducks was about 65\%. Ola (2000) observed carcass yield of between $66 \%$ and $68 \%$ in Muscovy ducks bred under semiintensive system in south western Nigeria. The dressing percentage of the male and female ducks within each breed, except of Dumyati breed, was significantly different from each other, the males of Muscovy and Sudani tended to have higher values than the females of the same breed. Inversely, within Peking breed, the females tended to have higher dressing values than males.

Table 2. Relative weight of carcass characteristics of ducks as affected by strain, sex and their interaction

\begin{tabular}{|c|c|c|c|c|c|c|c|c|c|}
\hline \multirow[b]{2}{*}{ Sex } & \multicolumn{4}{|c|}{ Breed } & \multirow[b]{2}{*}{ Overall } & \multirow{2}{*}{$\begin{array}{l}\text { Pooled } \\
\text { S.E.M }\end{array}$} & \multicolumn{3}{|c|}{$\begin{array}{c}\text { Level of } \\
\text { significance }\end{array}$} \\
\hline & Dumyati & Muscovy & Peking & Sudani & & & $\mathrm{B}$ & S & $\mathrm{B} * \mathrm{~S}$ \\
\hline \multicolumn{10}{|c|}{ Blood, \% } \\
\hline Female & 5.41 & 4.72 & 5.52 & 5.72 & $5.34^{\mathrm{b}}$ & 0.09 & & & \\
\hline Male & 5.72 & 5.41 & 5.70 & 6.41 & $5.81^{\mathrm{a}}$ & 0.12 & & & \\
\hline Overall & $5.57^{\mathrm{b}}$ & $5.07^{\mathrm{c}}$ & $5.61^{\mathrm{b}}$ & $6.07^{\mathrm{a}}$ & & & 0.01 & 0.01 & 0.02 \\
\hline \multicolumn{10}{|c|}{ Feather, \% } \\
\hline Female & 5.68 & 5.41 & 5.80 & 5.82 & $5.88^{\mathrm{b}}$ & 0.11 & & & \\
\hline Male & 6.43 & 6.17 & 6.38 & 6.40 & $6.35^{\mathrm{a}}$ & 0.08 & & & \\
\hline Overall & $6.06^{\mathrm{a}}$ & $5.79^{\mathrm{b}}$ & $6.09^{\mathrm{a}}$ & $6.11^{\mathrm{a}}$ & & & 0.05 & 0.01 & NS \\
\hline \multicolumn{10}{|c|}{ Dressing, \% } \\
\hline Female & 65.11 & 69.54 & 68.70 & 66.85 & 67.80 & 0.58 & & & \\
\hline Male & 65.14 & 71.22 & 66.57 & 67.15 & 67.52 & 0.61 & & & \\
\hline Overall & $65.13^{\mathrm{c}}$ & $70.38^{\mathrm{a}}$ & $67.64^{\mathrm{b}}$ & 67.00 & & & 0.01 & NS & 0.05 \\
\hline \multicolumn{10}{|c|}{ Gizzard, \% } \\
\hline Female & 3.22 & 2.54 & 3.31 & 2.73 & 2.95 & 0.07 & & & \\
\hline Male & 3.30 & 2.63 & 3.41 & 2.79 & 3.03 & 0.05 & & & \\
\hline Overall & $3.26 \mathrm{a}$ & $2.59 \mathrm{~b}$ & $3.36 \mathrm{a}$ & $2.76 \mathrm{~b}$ & & & 0.01 & NS & NS \\
\hline \multicolumn{10}{|c|}{ Liver, \% } \\
\hline Female & 2.10 & 2.53 & 2.37 & 2.48 & 2.37 & 0.03 & & & \\
\hline Male & 1.98 & 2.51 & 2.64 & 2.68 & 2.45 & 0.08 & & & \\
\hline Overall & $2.04^{\mathrm{b}}$ & $2.52^{\mathrm{a}}$ & $2.50^{\mathrm{a}}$ & $2.58^{\mathrm{a}}$ & & & & & \\
\hline \multicolumn{10}{|c|}{ Heart, \% } \\
\hline Female & 0.69 & 0.75 & 0.72 & 0.87 & 0.76 & 0.02 & & & \\
\hline Male & 0.73 & 0.79 & 0.63 & 0.81 & 0.74 & 0.03 & & & \\
\hline Overall & $0.71^{\mathrm{c}}$ & $0.77^{\mathrm{b}}$ & $0.68^{\mathrm{c}}$ & $0.84^{\mathrm{a}}$ & & & 0.001 & NS & NS \\
\hline \multicolumn{10}{|c|}{ Giblets, \% } \\
\hline Female & 6.01 & 5.82 & 6.40 & 6.08 & 6.08 & 0.13 & & & \\
\hline Male & 6.01 & 5.93 & 6.68 & 6.28 & 6.23 & 0.10 & & & \\
\hline Overall & $6.01 \mathrm{~b}$ & $5.88 \mathrm{~b}$ & $6.54 \mathrm{a}$ & $6.18 \mathrm{ab}$ & & & 0.05 & NS & NS \\
\hline \multicolumn{10}{|c|}{ Abdominal fat, \% } \\
\hline Female & 1.67 & 1.22 & 3.85 & 1.31 & $2.01^{\mathrm{a}}$ & 0.08 & & & \\
\hline Male & 1.48 & 1.09 & 2.17 & 1.28 & $1.50^{\mathrm{b}}$ & 0.05 & & & \\
\hline Overall & $1.58^{\mathrm{b}}$ & $1.16^{\mathrm{c}}$ & $3.01^{\mathrm{a}}$ & $1.30 b^{c}$ & & & 0.001 & 0.01 & 0.05 \\
\hline \multicolumn{10}{|c|}{ Breast muscle, \% } \\
\hline Female & 14.51 & 18.37 & 18.85 & 16.12 & $16.96^{\mathrm{b}}$ & 0.21 & & & \\
\hline
\end{tabular}




\begin{tabular}{llllllllll} 
Male & 14.72 & 20.81 & 15.12 & 18.54 & $17.30^{\mathrm{a}}$ & 0.35 & & & \\
Overall & $14.62^{\mathrm{c}}$ & $19.59^{\mathrm{a}}$ & $16.99^{\mathrm{b}}$ & $17.33^{\mathrm{b}}$ & & & 0.001 & 0.03 & 0.01 \\
\hline
\end{tabular}

The Muscovy ducks had significantly lowest abdominal fat percentage compared to other groups. Similar trend was noticed for Sudani and Dumyati when compared with Peking one. Szasz and Bogenfurst (1998) indicated that at 12 weeks the Pekin ducks had fat percentages of 20 vs 12 in the Muscovy and Mule ducks. Other researchers (Garachka and Kas Yanenka 1994) reported body fat percentages for Pekin and Muscovy ducks to be 35-37.5 and 21.0-21.7\% respectively. The result from this trial indicated that the Muscovy ducks possess better quality meat than the Pekin due to lower body fat.

\section{Chemical analysis of breast meat ducks:}

Chemical analysis of breast and thigh meat ducks as affected by strain, sex and their interaction are presented in Tables ( $3 \& 4)$. It could be noticed that the water content in breast meat was significantly affected by strain, whereas the Peking strain had significantly higher water content in breast compared than Dumyati. Both Muscovy and Sudani ducks were intermediate. Regardless of strain, the present result indicated that the female ducks had significantly lower water content in breast meat compared to drakes one. According to Witkiewicz $(1998,2000)$ water content of muscles of 7-week-old A44 and A55 Peking ducks ranged from 75.2\% to 76.6\%. An even greater water content of breast muscle in Peking ducks was reported by Smith $e t$ al. (1993). The water content in breast was not significantly affected by interaction between strain and sex. Regarding thigh muscle, our result indicated that the water content of Peking thigh muscle was significantly higher than that of Muscovy ones. The thigh muscle water content of male was significantly higher than that of female.

Table 3. Chemical analysis of breast meat ducks as affected by strain, sex and their interaction

\begin{tabular}{|c|c|c|c|c|c|c|c|c|c|}
\hline \multirow[b]{2}{*}{ Sex } & \multicolumn{4}{|c|}{ Breed } & \multirow[b]{2}{*}{ Overall } & \multirow{2}{*}{$\begin{array}{l}\text { Pooled } \\
\text { S.E.M }\end{array}$} & \multicolumn{3}{|c|}{ Prob. } \\
\hline & Dumyati & Muscovy & Peking & Sudani & & & $\mathrm{B}$ & $\mathrm{S}$ & $\mathrm{B} * \mathrm{~S}$ \\
\hline \multicolumn{10}{|c|}{ Moisture, \% } \\
\hline Female & 73.90 & 74.34 & 74.50 & 74.52 & $74.32^{\mathrm{b}}$ & 0.23 & & & \\
\hline Male & 74.35 & 74.72 & 75.35 & 74.78 & $74.80^{\mathrm{a}}$ & 0.29 & & & \\
\hline Overall & $74.13^{\mathrm{b}}$ & $74.53^{\mathrm{ab}}$ & $74.93^{\mathrm{a}}$ & $74.65^{\mathrm{ab}}$ & & & 0.02 & 0.01 & NS \\
\hline \multicolumn{10}{|c|}{ Protein, \% } \\
\hline Female & 20.20 & 19.39 & 18.92 & 20.39 & $19.72^{\mathrm{b}}$ & 0.18 & & & \\
\hline Male & 20.77 & 19.65 & 19.65 & 20.61 & $20.17^{\mathrm{a}}$ & 0.12 & & & \\
\hline Overall & $20.48^{\mathrm{a}}$ & $19.52^{\mathrm{b}}$ & $19.28^{\mathrm{b}}$ & $20.50^{\mathrm{a}}$ & & & 0.001 & 0.001 & NS \\
\hline \multicolumn{10}{|c|}{ Fat, \% } \\
\hline Female & 3.40 & 3.86 & 4.48 & 2.84 & $3.65^{\mathrm{a}}$ & 0.12 & & & \\
\hline Male & 2.60 & 3.70 & 3.40 & 2.76 & $3.12^{\mathrm{b}}$ & 0.08 & & & \\
\hline Overall & $3.00^{\mathrm{b}}$ & $3.78^{\mathrm{a}}$ & $3.74^{\mathrm{a}}$ & $2.80^{\mathrm{b}}$ & & & 0.001 & 0.001 & 0.001 \\
\hline \multicolumn{10}{|c|}{ Ash, \% } \\
\hline Female & 1.85 & 2.14 & 1.25 & 2.16 & $1.85^{\mathrm{a}}$ & 0.06 & & & \\
\hline Male & 1.95 & 1.60 & 1.43 & 1.60 & $1.67^{\mathrm{b}}$ & 0.11 & & & \\
\hline Overall & $1.90^{\mathrm{a}}$ & $1.87^{\mathrm{a}}$ & $1.34^{\mathrm{b}}$ & $1.92^{\mathrm{a}}$ & & & 0.001 & 0.001 & 0.001 \\
\hline
\end{tabular}


Table 4. Chemical analysis of thigh meat of ducks as affected by strain, sex and their interaction

\begin{tabular}{|c|c|c|c|c|c|c|c|c|c|}
\hline \multirow[b]{2}{*}{ Sex } & \multicolumn{4}{|c|}{ Breed } & \multirow[b]{2}{*}{ Overall } & \multirow{2}{*}{$\begin{array}{l}\text { Pooled } \\
\text { S.E.M }\end{array}$} & \multicolumn{3}{|c|}{ Prob. } \\
\hline & Dumyati & Muscovy & Peking & Sudani & & & $\mathrm{B}$ & $\mathrm{S}$ & $\mathrm{B} * \mathrm{~S}$ \\
\hline \multicolumn{10}{|c|}{ Moisture, \% } \\
\hline Female & 74.52 & 74.80 & 75.30 & 74.60 & $74.80^{\mathrm{a}}$ & 0.40 & & & \\
\hline Male & 75.75 & 74.94 & 76.17 & 75.78 & $75.66^{\mathrm{b}}$ & 0.35 & & & \\
\hline Overall & $75.13^{\mathrm{b}}$ & $74.87^{\mathrm{b}}$ & $75.73^{\mathrm{a}}$ & $75.19^{b}$ & & & 0.01 & 0.001 & NS \\
\hline \multicolumn{10}{|c|}{ Protein, \% } \\
\hline Female & 18.30 & 18.30 & 17.80 & 19.19 & $18.40^{\mathrm{b}}$ & 0.21 & & & \\
\hline Male & 19.08 & 18.38 & 18.30 & 19.33 & $18.77^{\mathrm{a}}$ & 0.18 & & & \\
\hline Overall & $18.69^{\mathrm{b}}$ & $18.34^{\mathrm{c}}$ & $18.05^{\mathrm{c}}$ & $19.26^{\mathrm{a}}$ & & & 0.0001 & 0.01 & NS \\
\hline \multicolumn{10}{|c|}{ Fat, $\%$} \\
\hline Female & 5.00 & 5.46 & 5.40 & 4.57 & $5.11^{\mathrm{a}}$ & 0.13 & & & \\
\hline Male & 3.30 & 3.92 & 4.10 & 2.97 & $3.57^{\mathrm{b}}$ & 0.14 & & & \\
\hline Overall & $4.15^{\mathrm{b}}$ & $4.69^{\mathrm{a}}$ & $4.75^{\mathrm{a}}$ & $3.77^{\mathrm{c}}$ & & & 0.001 & 0.001 & NS \\
\hline \multicolumn{10}{|c|}{ Ash, \% } \\
\hline Female & 1.58 & 1.34 & 1.06 & 1.41 & $1.54^{\mathrm{a}}$ & 0.09 & & & \\
\hline Male & 1.68 & 1.56 & 1.27 & 1.63 & $1.35^{\mathrm{b}}$ & 0.05 & & & \\
\hline Overall & $1.63^{\mathrm{a}}$ & $1.45^{\mathrm{b}}$ & $1.16^{\mathrm{c}}$ & $1.52^{\mathrm{ab}}$ & & & 0.001 & 0.001 & NS \\
\hline
\end{tabular}

With respect to protein \%, the present result showed that both Domyitte and Sudani ducks had significantly higher protein percentage in breast compared to remaining strains. The male ducks had significantly higher protein percentage in breast compared to female ones. According to Witkiewicz $(1998,2000)$ in 7 -weekold A44 and A55 ducks of both sexes, the protein content of breast muscles was 21.1 and $20.7 \%$, respectively. An even greater protein content of breast muscles $(21.5 \%)$ and leg muscles $(22.5 \%)$ of Peking ducks was noted by Bons et al. $(1998,1999)$. The fat contents of breast muscle of 7-week-old A44 and A55 males (1.4 and 2.3\%, respectively) and females (2.0 and $2.5 \%$, respectively) as determined by Witkiewicz $(1998,2000)$, were similar or lower than shown in the present report.

Concerning fat percentage, it could be observed that both Peking and Muscovy ducks had significantly higher fat percentage in breast compared to other strains. The fat content in the breast of female ducks was significantly higher than that of female ones. The fat content was significantly affected by interaction between strain and sex. The last result could be attributed to the either Domyitte or Peking female ducks had higher fat content in breast compared to male ones. Similar trend did not observe in Muscovy and Sudani breeds. The fat content of breast muscles higher than reported here was found in Peking ducks by Bons et al. (1998, 1999), Pingel and Birla (1981ab) and Smith et al. (1993). In the present study, the fat content of breast muscles was low (1.7\%), while in leg muscles markedly higher (3.9\%).

The ash content in breast meat of Peking ducks was significantly lower than those of other strains. Also, the male ducks had significantly lower ash content in breast area compared to female ones. The ash content did significantly affected by interaction between strain and sex. This result could be attributed to the effect of sex on ash content was more pronounced in both Muscovy and Sudani brreds rather than both of Domyitte and Peking ones. Bons et al. (1999) in leg muscles of 7-week-old 
ducks reported a higher content of ash (1.4\%) than in 8-week-old A44 and A55 ducks of both sexes $(1.1 \%)$.

\section{In vivo cell-mediated immunity}

The PHA-P intradermally reaction, a T-lymphocyte-dependent response, has been well researched and has been shown to be a reliable indicator of in viva cellular immunity in poultry (Goto et al. 1978 and McCorkle et al. 1980). The skin response reflects a complex series of physiological events such as mitogen-receptor and lymphocyte-macrophage interactions, release of chemical mediators, cellular proliferation, and changes in vascularity (Chandra and Newberne 1977). Histologically, PHA-P is strongly mitogenic to T-lymphocytes, and intradermali injections elicit macrophage infiltration and dense perivascular accumulations of lymphocytes 24h post-injection in chickens (Goto et al. 1978 and McCorkle et al. 1980). The increased infiltration by basophils and eosinophils $24 \mathrm{~h}$ post-injection has been described as a cutaneous basophil hypersensitivity response (Stadecker et al. 1977). In vivo cell-mediated immune response as measured by PHA stimulation (toeweb) is presented in Figure (1). The present result indicated that the Dumyati strain in both sexes had significantly hyper responder to PHA-P injection at all times compared to other strains. There was no significant difference between Muscovy and Sudani strains for responses to PHA-P injection. Moreover, the Peking strain recorded the lowest response to PHA-P injection. Regardless strain effect, it could be noticed that the females had significantly hyper responder to PHA-P injection than males. There was a good indication that cell-mediated immunity plays an important role in controlling and clearing intracellular bacterium (Kougt et al., 1994, 1995).

In conclusion, the results obtained in this study give some insight into the production parameters and immune response of the four breeds of ducks present in Egypt. The Muscovy ducks had a better performance and carcass characteristics; however, the Dumyati breed had a hyper responder to PHA-P injection compared to other breeds. 


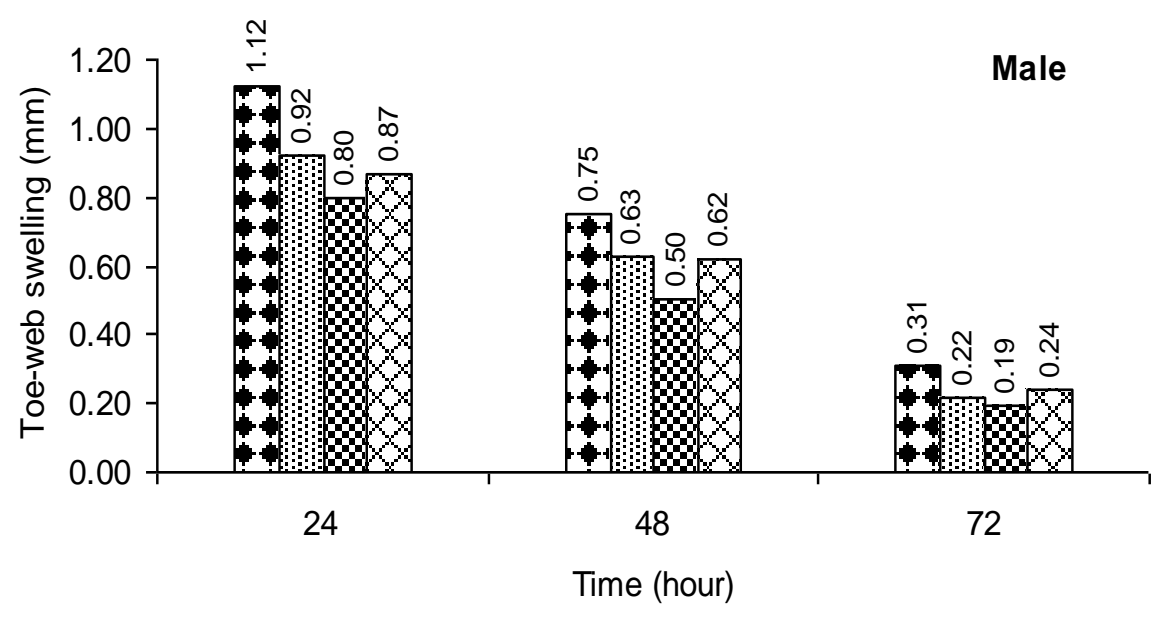

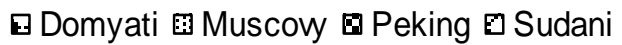

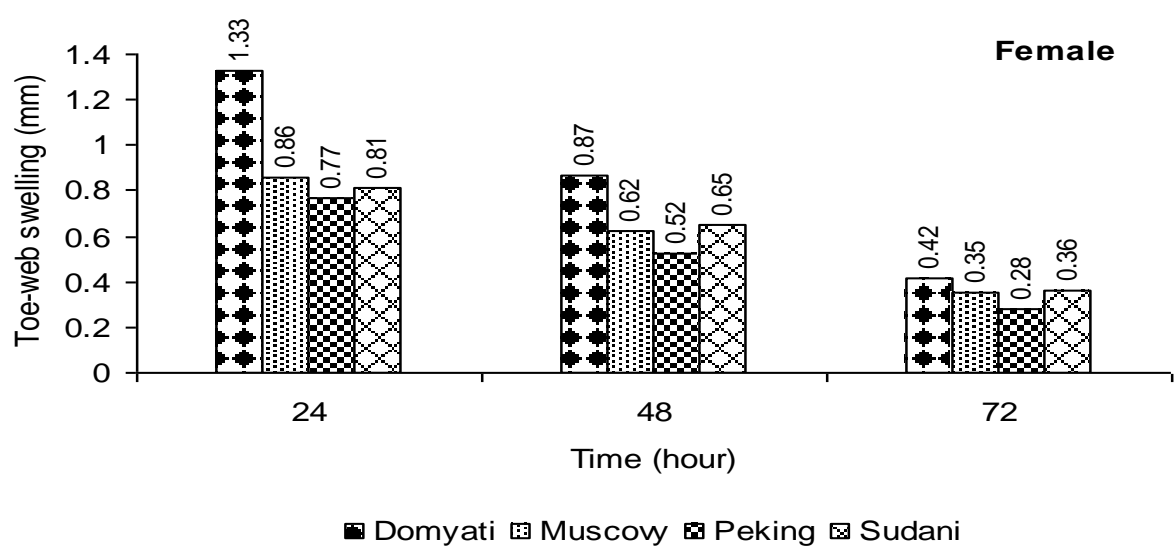

Fig. 1. Toe-web swelling of duck as affected by breed, sex and their interaction

\section{REFERENCES}

Bochno, R., A. Lewczuk and E. Wawko, 1994. Comparison of growth and feed conversion efficiency of Muscovy and Pekin ducks, Poultry Abstract 1994 Volume 20. Number3, 18 CAB International.

Bochno, R., A. Lewczuk, A. Janiszewska, A. Mazanowski and K. Wawro, 1988. Zastosowanie równań regresji wielokrotnej do oceny umięśnienia i otłuszczenia kaczek (Use of multiple regression equations for evalution of muscle and fat weight of ducks). In Polish with English summary. Acta Academiae Agriculturae ac Technicae Olstenensis 31, 197-203. 
Bochno, R., A. Lewczuk, E. Wawro and A. Mazanowski, 1984. Tempo wzrostu ilości poszczególnych składników tkankowych w tuszkach kaczek (Growth rate of particular tissue components of ducks' carcasses). In Polish with English summary. Przegląd Naukowej Literatury Zootechnicznej 30 (3-4), 113-117.

Bons, A., Timmler R. and Jeroch H. (1998). Changes in body composition and content of fat and protein in carcass of male and female Pekin ducks during growth. Zeszyty Naukowe Przeglądu Hodowlanego 36, 165-175.

Bons, A., Timmler R. and Jeroch H. (1999). Changes in body composition and crude nutrient content of Pekin ducks during growth. Proceedings of First World's Waterfowl Conference, December 1-4, Taichung, 328-332.

Carew, B.A.R., W.A. Ajetunmobi, F.O. Elesin and F.A. Dacosta, 1998. Carcass qualities of poultry species in Lagos metropolis - The sustainability question. Proceedings of the Silver Anniversary Conference of NSAP/WASAP Inaugural Conference, 462 - 463.

Chandra, R.K. and P.M. Newberne (1977). Nutrition, immunity, and infections. Plenum Press, New York.

Duong X T and Nguyen C Q 1995. Studies on the performance of CV Super-M duck breed in the Southern provinces of Vietnam. Poultry Abstract 1997 Volume 23 Number 5, 140 CAB International.

Garachka M S T and Kas Yanenka S V 1994 Meat composition of hybrid ducklings. Poultry Abstract 1997 Volume 23 Number 5, 114 CAB International

Gorski J. (1990). Wzrost i proporcje podrobów, produktów ubocznych i składników tkankowych tuszki u kaczek rasy pekin w okresie odchowu (Growth and mutual ratio of giblets, offals and tissue elements in Pekin duck carcasses during rearing period). In Polish with English summary. Przegląd Naukowej Literatury Zootechnicznej 35, 147-154.

Gorski J. (1997a). The effect of two-way crossbreeding of Pekin ducks of P-11, P-22, P-44 and P-55 strains on fleshing and fatness of crossbred ducks. Proceedings of 11th European Symposium on Waterfowl. September 8-10, Nantes, 354-360.

Gorski J. (1997b). The effects of two-way crossbreeding of Pekin ducks of P-11, P22, P-44 and P-55 strains of fat and protein content in the muscles of crossbred ducks. Proceedings of 11th European Symposium on Waterfowl. September 8-10, Nantes, 362-367.

Goto, N., H. Kodama, K. Okada and Y. Fujimoto (1978). Suppression of phytohemagglutinin skin response in thymoectomized chicken. Poultry Sci., 57:246-250.

Knust U. and Pingel H. (1992). The effect of initial pH-value in duck breast and thigh muscle on other meat characteristics. Proceedings of the 19th World's Poultry Congress. September 20-24, Amsterdam, 3, 221-224.

Kougt, M.H., McGrude, E.D., Hargis, B.M., Corrier, D.E. and Deloach, J.R. (1994). Characterization of the pattern of inflammatory cell influx in chicks following the intraperitoneal administration of line Salmonella enteritidies-immune lymphokines. Poult. Sci. 74:8-17.

Kougt, M.H., McGrude, E.D., Hargis, B.M., Corrier, D.E. and Deloach, J.R. (1995). In vivo activation of heterophil function in chickens following injection with Salmonella enteritidies-immune lymphokines. J. of Leukocyte Biol. 57:56-62. 
Loung T N, Hoang V T, Dang T D, Le X T, Doan V X and Nguyen D T 1995 Growth and meat performance of CV Super-M ducks under two management systems in the Red River Delta. Poultry Abstract 1997 Volume 23 Number 5, 140 CAB International.

McCorkle, F., I. Ola and B. Glick (1980). The morphology of the phytohemagglutinin-induced cell responsein the chicken'sw attle. Poult. Sci. 59:616-623.

Ola, S.I., 2000. Vital reproductive and productive characteristics of the Nigerian Muscovy duck. Proceedings of the 25th Annual NSAP Conference, 188 - 190.

Perez R 1985 Duck - Rearing manual, University of the West Indies, St Augustine, Trinidad.

Pikul J., Doruchowski W., Tanski S. and Reksinski T. (1987). Porównanie wydajności poubojowej i dysekcyjnej, składu chemicznego oraz właściwości technologicznych mięsa kaczek piżmowych i Pekin (Slaughter yields, carcass composition, chemical analysis and technological properties of muscovy and Pekin ducks). In Polish with English summary. Zeszyty Naukowe Drobiarstwa 4, 73-92.

Pingel, H. and Birla M. (1981a). Poprawa jakości tuszki kaczek przez selekcję (Improvement of duck carcass quality by selection). In Polish with English summary. Prace Badawcze Zakładu Hodowli Drobiu (Instytut Zootechniki) 9, 127-131.

Pingel, H. and Birla M. (1981b). Wpływ czynników przedubojowych na jakość tuszki u ptactwa wodnego (The effect of antemortem factors on the carcass quality of waterfowl). In Polish with English summary. Prace Badawcze Zakładu Hodowli Drobiu (Instytut Zootechniki) 9, 121-126.

SAS Institute, 2001. SAS/STAT User's Guide Version 8.2 ed: Statistics. SAS Institute Inc., Cary, NC.

Sauveur, B., 1990. Effect of sex on growth, technological and organoleptic characteristics of the Muscovy duck breast muscle. Baeza, E., Salichon, M.R. \& March, G. British Poultry Science. 1998. 39: 389-403.

Smith, D.P., Fletcher, D.L., Buhr, R.J. and Beyer R.S. (1993). Pecking duckling and broiler chicken pectoralis muscle structure and composition. Poultry Science 72, 202-208.

Stadecker, J., M. Luk, C.A . DVORAK and S. Leskowitz (1977). The cutaneous basophil response to phytohemagglutininin chickens. J. Immunol. 118:1564-1568.

Stevens, P. and Sauveur, B. 1985. Duck production and management in France. Duck production Science and World Pratice. Farell, D.J. \& Stapleton, P. (Ed). University of New England. Pp. 248-257.

Szasz, S. and F. Bogenfurst, 1998. Study on body fat content in Peking, Muscovy and mule ducks. Proceedings of the 10th European Poultry Conference, Jerusalem: 719- 722 .

Szasz, S., 2003. Changes in feather development and meat producing capacity of the Peking, mule and Muscovy ducks according to the age and sex. Ph. D. Dissertation Thesis. University of Kaposvar, Hungary: 1- 17.

Vander Sluis W 1993 Waterfowl production increasing slowly, World Poultry Misset Volume 9 Number 8/9 93. 
Wiseman, J. 1987. Feeding of Non-Ruminant Livestock. Butterworths, pp. 102-109. Zanella, I., Sakomura, N.K., Silversides, F.G., Fiquerdo, A. \& Pack, M. 1999. Effect of enzyme supplementation of broiler diets based on corn and soybeans. Poultry Science. 78: 561-568.

Witkiewicz K. (1998). Porównanie kaczek z dwóch rodów hodowlanych pod względem wybranych cech przyżyciowych i poubojowych (Comparison of ducks from two breeding strains with regard to some selected live and slaughter traits). In Polish with English summary. Roczniki Akademii Rolniczej w Poznaniu 302, 243-251.

Witkiewicz K. (2000). Pomiary zoometryczne, wartość rzeźna i skład chemiczny mięśnia piersiowego u dwu rodów kaczek typu pekin (Zoometric measurements, slaughter value and chemical composition of the breast muscle in two strains of ducks of Pekin type). In Polish with English summary. Roczniki Akademii Rolniczej w Poznaniu 330, 231-240.

Woloszyn J., Ksiazkiewicz J., Orkusz A., Skrabka-Blotnicka T., Biernat J. and Kisiel T. (2002). Preliminary evaluation of chemical composition of duck's muscles from two Polish conservative flocks. Proceedings of 48th International Congress of Meat Science and Technology. August 25-30, Rome, 374-375. 


\section{الاداء الإنتاجى و خصائص الأبيحة للبط الدمياطى والمسكوفى والبكينى والسودانى}

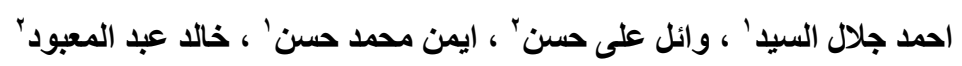

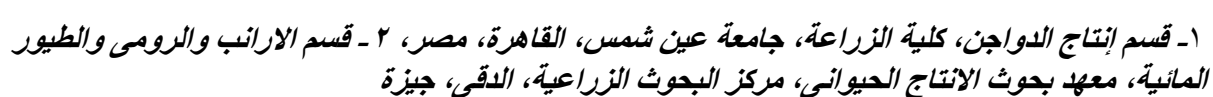

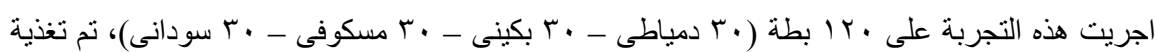

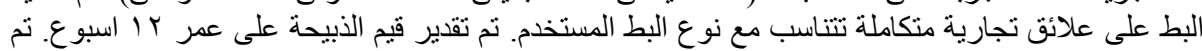

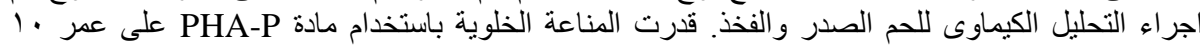

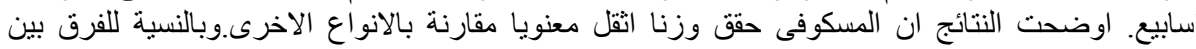

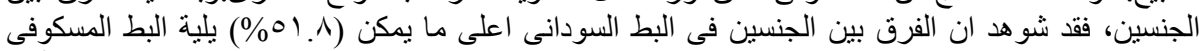

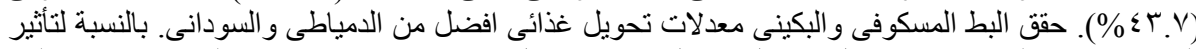

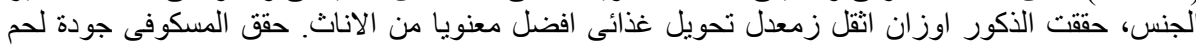

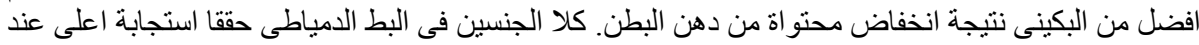

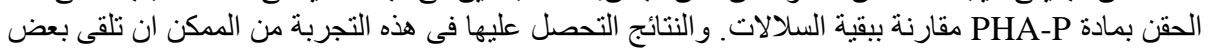

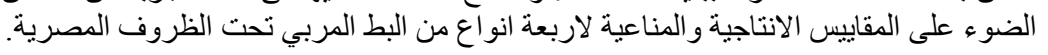

